\title{
Contents, Volume 4 (1993)
}

Al-Safadi, M. M.: see Linnavuori, R. E. \& Al-Safadi, M. M. .......................................................... 169

Al-Safadi, M. M.: see Linnavuori, R. E. \& Al-Safadi, M. M......................................................... 179

Al-Safadi, M. M.: see Linnavuori, R. E. \& Al-Safadi, M. M................................................................. 233

Al-Safadi, M. M.: see Linnavuori, R. E. \& Al-Safadi, M. M. ........................................................... 235

Al-Safadi, M. M.: see Linnavuori, R. E. \& Al-Safadi, M. M. 241

Barkalov, A. V.: Taxonomy and distribution of six Palaearctic Cheilosia species (Diptera, Syrphidae) ...... 207

Clayhills, T.: Interesting Coleoptera finds from southwestern Finland.

Clayhills, T.: Phloeopora opaca Bernhauer (Coleoptera, Staphylinidae) new to Finland. 16

Engblom, E., Lingdell, P.-E., Nilsson, A. N. \& Savolainen, E.: The genus Metretopus (Ephemeroptera, Siphlonuridae) in Fennoscandia - identification, faunistics and natural history 213

Halme, J.: see Koponen, M. \& Halme, J. ...................... 31 Itämies, J., Kuusela, K. \& Karvonen, K.: Distribution of Atherix ibis (Diptera, Athericidae) in Fennoscandia ...

161

Itämies, J.: see Laine, A., Itämies, J. \& Orell, M. ...... 201

Itämies, J.: see Pulliainen, E., Itämies, J., Jussila, P. \& Tunkkari, P. 27

Johansson, F.: The distribution of Odonata in Västerbotten and South Lapland, northern Sweden 165

Jussila, P.: see Pulliainen, E., Itämies, J., Jussila, P. \& Tunkkari, P.

27

Kaila, L.: A new method for collecting quantitative samples of insects associated with decaying wood or wood fungi

21

Kangas, E. \& Rutanen, I.: Identification of females of the Finnish species of Altica Müller (Coleoptera, Chrysomelidae)

115

Karvonen, K.; see Itämies, J., Kuusela, K. \& Karvonen, K. 161

Kjærandsen, J.: Diptera in mines and other cave systems in southern Norway 151

Koponen, M. \& Halme, J.: New finds of Ephedrus and Toxares species (Hymenoptera, Braconidae, Aphidiinae) from Finland

31

Kuusela, K.: see Itämies, J., Kuusela, K. \& Karvonen, K. 161

Laine, A., Itämies, J. \& Orell, M.: The Psocoptera of Norway spruce (Picea abies) branches in northem Finland 201
Lammes, T. \& Rinne, V.: New and corrected records on distribution of Finnish Heteroptera ......................... 19

Lingdell, P.-E.: see Engblom, E., Lingdell, P.-E., Nilsson, A. N. \& Savolainen, E. ....................................... 213

Linnavuori, R. E. \& Al-Safadi, M. M.: Acrorrhinium Noualhier and Compsonannus Reuter (Heteroptera, Miridae) in the Middle East ................................... 169

Linnavuori, R. E. \& Al-Safadi, M. M.: Acrosternum Fieber (Heteroptera, Pentatomidae) in the Arabian Peninsula

235

Linnavuori, R. E. \& Al-Safadi, M. M.: New species of Campylomma and Cyrtopeltis (Hemiptera, Miridae) from Yemen ....................................................... 241

Linnavuori, R. E. \& Al-Safadi, M. M.: New species of Miridae (Hemiptera, Heteroptera) from Yemen .. 179

Linnavuori, R. E. \& Al-Safadi, M. M.: Nomenclatural note on the genus Moissonia Reuter (Hemiptera, Miridae, Phylinae)

233

Linnavuori, R. E.: Hemiptera of Iraq. II. Cydnidae, Thaumastellidae, Pentatomidae, Stenocephalidae, $\mathrm{Co}$ reidae, Alydidae, Rhopalidae, and Pyrrhocoridae .. 37

Linnavuori, R. E.: Hemiptera of Iraq. III. Heteroptera, Miridae (Phylinae) 253

Löyttyniemi, K. \& Löyttyniemi, R.: Cleridae (Coleoptera) from miombo woodland in Zambia ...................... 223

Löyttyniemi, R.: see Löyttyniemi, K. \& Löyttyniemi, R. .. 223

Mannerkoski, I.: Bibliography of Esko Kangas .............. 3

Niemi, R. \& Skubała, P.: New species of Moritzoppia and Medioppia from the Beskidy Mountains, Poland (Acarina, Oribatida, Oppiidae) .............................. 195

Nilsson, A. N. \& Persson, S.: Taxonomy, distribution and habitats of the Dytiscidae (Coleoptera) of Ethiopia .. 57

Nilsson, A. N.: see Engblom, E., Lingdell, P.-E., Nilsson, A. N. \& Savolainen, E. .......................................... 213

Nuorteva, M.: Esko Kangas — In memoriam ................ 1

Orell, M.: see Laine, A., Itämies, J. \& Orell, M. ........ 201

Pape, T.: The Sarcophagidae (Diptera) described by C. De Geer, J. H. S. Siebke, and O. Ringdahl ............... 143

Persson, S.: see Nilsson, A. N. \& Persson, S. ............... 57 Pulliainen, E., Itämies, J., Jussila, P. \& Tunkkari, P.: Phenology and habitats of Carabus glabratus Paykull (Coleoptera, Carabidae) in NE Finland ................... 27

Rinne, V.: see Lammes, T. \& Rinne, V. ...................... 19

Rutanen, I.: Epuraea concurrens Sjöberg (Coleoptera, Nitidulidae) new to Europe ....................................... 25

Rutanen, I.: see Kangas, E. \& Rutanen, I. ................... 115 Savolainen, E.: see Engblom, E., Lingdell, P.-E., Nilsson, A. N. \& Savolainen, E........................................ 213 
Schroeder, L. M.: Attraction of Epuraea bickhardti St.Claire Deville and E. boreella (Zetterstedt) (Coleoptera, Nitidulidae) to ethanol and $\alpha$-pinene 133

Siitonen, J.: Faunistic records of Carabidae and Staphylinidae (Coleoptera) caught by pitfall trapping in western Finnish Lapland 225

Skubała, P.: see Niemi, R. \& Skubała, P. 195

Tomminen, J.: Development of Monochamus galloprovincialis (Coleoptera, Cerambycidae) in cut trees of young pines (Pinus sylvestris L.) and log bolts in southern Finland. 137

Tunkkari, P.: see Pulliainen, E., Itämies, J., Jussila, P. \& Tunkkari, $P$.

27

Tuovinen, T.: Identification and occurrence of phytoseiid mites (Gamasina: Phytoseiidae) in Finnish apple plantations and their surroundings .95

\section{Short reports}

Albrecht, A.: A record of Semiaphis nolitangere (Aizenberg) (Homoptera, Aphididae, Macrosiphinae) from Finland ... 12

Albrecht, A.: Anoecia zirnitsi Mordvilko (Homoptera, Anoeciidae) new to Finland ... 10

Albrecht, A.: Aphis lotiradicis Stroyan (Homoptera, Aphididae, Aphidinae) new to Fennoscandia ... 11

Albrecht, A.: Aphis species new to Finland (Homoptera, Aphididae, Aphidinae) ... 11

Albrecht, A.: Formica cunicularia Latreille (Hymenoptera, Formicidae) new to Finland 13

Albrecht, A.: Macrosiphine aphids new to Finland (Homoptera, Aphididae, Macrosiphinae) 11

Albrecht, A.: Mamontova vera Shaposnikov (Homoptera, Aphididae, Macrosiphinae) new to the Nordic countries
Albrecht, A.: Phyllaphidine aphids new to Finland (Homoptera, Drepanosiphidae, Phyllaphidinidae) . 12 Clayhills, T.: Thyphaea decipiens Lohse (Coleoptera, Mycetophagidae) found in Finland ............................. 10

Faunistic rarities .......................................................... 14

Gannota, E.: Five species of Chorebus (Hymenoptera, Braconidae, Alysiinae, Dacnusini) new to Finland 13

Jussila, R.: Atractodes ruficollis Jussila (Hymenoptera, Ichneumonidae) new to Finland ... 13

Mannerkoski, I.: Attagenus fasciatus (Thunberg) (Coleoptera, Dermestidae), a new indoor pest found in Finland

Mannerkoski, I.: Further information on Typhaea decipiens Lohse (Coleoptera, Mycetophagidae) in Finland ... 10

New provincial records 13

Rinne, V.: Agallia estonica Vilbaste (Homoptera, Cicadellidae) new to Finland ....................................... 10

Silfverberg, H.: Anchomenus dorsalis (Pontoppidan) (Coleoptera, Carabidae) found in Åland .. 9

\section{Literature reviews}

Bernays, E. A. (ed.): Insect-Plant Interaction. Vol. IV. (U. Carlberg) 178

Brock, P. D. (ed.): Rearing and Studying Stick and LeafInsects. (U. Carlberg) 194

Burdon, J. J. \& Leather, S. R. (eds.): Pests, pathogens and plant communities (H. Hokkanen) 131

Johnson, C. (ed.): Provisional atlas of the CryptophagidaeAtomariinae (Coleoptera) of Britain and Ireland. (O. Biström). 234

Soós, Á., Papp, L. \& Oosterbroek, P. (eds.): Catalogue of Palaearctic Diptera. Volume 1. Trichoceridae - Nymphomyiidae. (F. Brodo \& P. Vilkamaa) 130 